\title{
"Just try to see it human, see it human": A Humanistic Psychological Reading to the Machiavellian Businessman in Arthur Miller's All My Sons
}

\author{
Maysoon Taher Muhi ${ }^{1 \& 2}$, Assoc. Prof. Tengku Sepora ${ }^{3}$

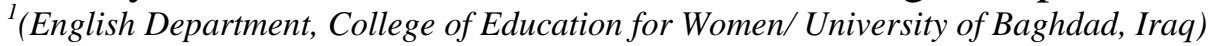 \\ ${ }^{2}$ (School of Language, Literacies, and Translation / Universiti Sains Malaysia, Malaysia) \\ ${ }^{3}$ (School of Language, Literacies, and Translation / Universiti Sains Malaysia, Malaysia)
}

\begin{abstract}
This paper argues that Miller's all My Sons(1947) shows how the cultural factors represented by politics, economics and social powers create characters who have certain Machiavellian features that can be explained by modern psychological theories. Instead of endeavoring to achieve their self-realization or actualization, these modern Machiavellian characters have lost their way and their human potentiality and become self-alienated. Arthur Miller's All My Sons (1947) has insightfully captured the disastrous effects of capitalism and cultural factors on his character. Miller's play demonstrates the influence of the modern increasing needs and the different strategies of coping with anxieties caused by the competitive capitalist society. The villainy of his businessman is seen more pity than contempt. The characters are defeated as society is defeated by the competitive spirit which brings out the worst in men and by the commercialism which perverts or hampered the traditional values. By applying a psychological approach of Abraham Maslow and Karen Horney's theories, this study aims to explore how Miller depicts the psychological sources of Machiavellian personality, the dynamics of inner conflict and the strategies that arise when character's bargain is threatened. This study applies Machiavellian personality theory that concentrates on the sense of Machiavellianism in modern time.
\end{abstract}

Keywords: All My Sons, Arthur Miller, Horney, Machiavellian, Maslow

\section{Introduction}

Machiavellianism is not a distinctly modern phenomenon. Its roots go back to the fifteenth century. Machiavellianism becomes a well-known theme at the Elizabethan time as Machiavellian character was related to power, control and devilish tactics to achieve the kings or princes ambitions However, the researcher wants to approach a particular form of Machiavellianism that is the modern one and has largely shaped modernism. In the modern time, the capitalism has distorted the American Dream and produced the Machiavellian orientation that pervades modern life. Caught between personal needs and public issues, represented by economics, sociology and politics, the modern man applies certain means to survive, but ironically instead of helping him to achieve self-actualization, they intensify his anxiety and self-alienation. The twentieth century dramatists, like Arthur Miller, the researcher believes, express and recognize how capitalism has rotten man's spirituality, making a pity modern monster that needs our sympathy and empathy.

However, for the last forty years or so, Machiavellian or Machiavellianism as a term has become a focus study of many psychologists, politicians, sociologists, economists, and educationists who all claim that Machiavellianism has a significant role in the formation of personality and behavior. This importance of Machiavellianism is greatly popularized in the late 1960s with the publication of social psychologists Richard Christie and Florance L. Geis book Studies in Machiavellianism. Many of Christie and Geis's insights and thoughts to study the psychology of human nature are derivative of the work, The Prince written by the Italian politician Niccolò di Bernardo dei Machiavelli (1469-1527). In their study, Christie and Geis consider Machiavelli not as "an historical figure," rather as "the sources of ideas about those who manipulate others" [1]. The Machiavellian impact in producing distinctive traits in individuals (leaders and politicians) during the twentieth century has been studied largely by some prominent political and philosophical writers like Leo Strauss and Quentin Skinner. Yet, none really gave Machiavellian a serious and sustained attention to describe the psychology of human nature of a common man until Christie and Geis in the late 1960s.

However, psychologists and sociologists have advanced a theory that Machiavellianism has an existence in all worlds from the old time to the recent time, yet its personality traits are intensified when there is a turmoil and chaos. It is a truism to mention that in the industrial societies after the World War II, which have become more complex and depersonalized, common man has been suffering from the feelings of alienation related to the past security of major belief systems, to his established social institutions, and even to himself as a 
person. In meeting the challenges of complex situations and experiences, the individual in modern world has developed patterns of behaviors and interactions with others to provide a means for surviving and satisfying his needs, allowing him to function actively within the constraints of modern life. It is worth mentioning that the cultural developments have intensified adjustment problems as well as have changed the ancestor effective value of coping mechanisms. The suppression of a direct use of physical power or force has shifted the attention to use other indirect. In addition, the feeling of alienation, accompanied by powerlessness, isolation, and meaninglessness has created a productive soil for intensifying and nourishing such Machiavellian actions like opportunistic, deceitful, lying and exploitative tactics.

\subsection{Studies in Machiavellian Characters in Literature \\ 2.1.2 Machiavellianism in Drama:}

\section{Literature Review}

The Italian cultural influence on the English style and theatrical structure is incontestable. However, many studies have traced the effect of Machiavelli on the English Renaissance stage. The Elizabethan attitude towards Machiavelli and Italian culture in general was an ambivalent. Machiavelli's thought, in particular, is proved to be revolting and enticing. Such ambivalence is reflected in the drama of Elizabethan age which adopted Machiavelli's political thoughts for two reasons; first, to impress audience by attracting their attention since Italian culture of aesthetic, freedom and love was welcomed and admired; and second to provide a cover for their political criticism [2].

There are abundant sources concerning the effect of Machiavellian thoughts on Elizabethan drama. The pioneering study of Meyer's (1897) Machiavelli and Elizabethan Drama highlights the role of Machiavellian thoughts in shaping Elizabethan stage, believing that Machiavellian characteristics which are intensified by the political climate and religious convictions are traceable in Marlowe's Paris, and Tamburlaine as well as in Shakespeare's Richard III [3]. In his dissertation, "Machiavellian Providential Politics in Marlowe and Shakespeare: A Comparative Perspective", Khoury's [4] attempts to extrapolate Shakespearean and Marlovian drama through Machiavelli's thoughts. He states his belief that both Shakespeare and Marlow 'Britainized' Machiavellian thoughts. Shakespeare dramatized the Italian thoughts within English history, stressing on the Machiavellian tactics to maneuver around the historical forces that could hinder the search for power. Marlowe, on the other hand, applied Machiavelli's thoughts in raw, without great stress on the social and historical obstacles that a ruler must handle. Both were able, as Khoury claims, to 'adopt' and 'adapt' the Italian thinker's thoughts, reformulating the question of political action to be compatible with the English culture. This study however concentrates on the political leaders or kings. Marlowe through Tamburlaine character explored the question of ultimate human power, how far it might be taken and what the results were of its application.

Sanders (1968) has addressed the dichotomization of the moral and the political discourse with their relation to Machiavelli's thought. Sanders maintained that in Shakespeare's Richard III, the "Machiavellian dilemma" structurally forms the play [5]. In Shakespeare and Machiavelli, John Alan Roe (2002) compares in detail between Shakespeare and Machiavelli as being playwrights and political philosophers, believing that both remarkably share a common ground of similarities in their motives and morality of political action. Roe concluded that Shakespeare's Richard III and Henry V used the same camouflaging tactics of Machiavelli The Prince, arguing that Shakespeare has built his plays on the Machiavellian concept of fortune which means destiny, fate, chance and uncertainty [2].

Grady (2002) studied the configuration and reconfiguration of themes of power and subjectivity in Shakespeare's drama which suggests, as Grady emphasized, Machiavelli's influence on Shakespeare's concept of the state ruled by one prince. He assumed that the classic works can be explained by modern theories of twentieth century, so that to bridge the gap between past and present and to see past in the eyes of the present. Grady, moreover, designated the influence of Machiavellian concept of power on theorists like Althusser, Foucault and Marx [4].

\subsubsection{The Neo-Machiavellianism:}

Since the 1970s a number of pioneering works of social, political, and psychological research, influenced by the theory of personality have demonstrated the pervasiveness of Machiavellian character in all walks of life. The footprint of Machiavelli's thoughts and ideas in society is represented clearly by Machiavellian orientation in interpersonal relation which is defined by manipulation and exploitation of people for selfish ends with relative lack of effect and without any concern for 'conventional morality' and 'ideological commitment'. The Machiavellian, thus, refers to someone who views and manipulates others for selfish ends. The Machiavellians view Man as an object to be manipulated and their views are directed to be more utilitarian than moral. The ideas expressed in the Machiavelli's book, The Prince were mainly associated with use of 
cunning, duplicity and opportunism in interpersonal relation, and one who is found to have such traits is termed as Machiavellian [1].

The bulk of scholarly studies show that Machiavellianism is found more or less in every individual but it is noted most obviously among politicians, businessmen and heads of institutions. The characteristics of Machiavellian personality are, to some extent, distinguished by external locus of control orientation [6],dogmatism [7], moderate anxiety [8], high risk-taking [9], ego strength [10], domination and low affability and responsibility [11], leadership qualities [12], and high value for power and utility [13]. Machiavellianism as a term is used widely in different fields. So, Machiavellianism in the modern world has been researched from a variety of perspectives. Although modern studies of Machiavellian personality do not entail any explanation of any dramatic work, their ideas, the researcher believes, are quite applicable to the dramatic Machiavellian characters in American drama.

\section{The Humanistic Psychology 'Third Force Psychology': Maslovian and Horneyan Theory 3.1 Introduction:}

The term Humanistic Psychology was coined by some psychologists, headed by Abraham Maslow in 1962. This group started a movement referred to as Third-Force Psychology, claiming that the other two forces in psychology, behaviorism and Freudianism, have neglected a number of important human attributes. They have criticized the Behaviorism techniques that rendered human beings to merely robots, lower animals, or computers, as they think that there was nothing unique about humans. Their major argument against Freudianism was related to its heavy concentration on instincts and on emotionally disturbed people. According to the Humanistic psychologists, the Third Force psychology is an attempt to address what was missing, and to study human being holistically. This psychology has argued that man is not simply and merely a "tensionreducing" or a conditioned animal, but there is another third force which is an "evolutionary constructive" force, that urges "him to realize his given potentialities" (Horney, 1999: 15). Moreover, the focus of humanistic psychology is

upon the specificity of man, upon that which sets him apart from all other species. It differs from other psychologies because it views man not solely as a biological organism modified by experience and culture but as a person, a symbolic entity capable of pondering his existence, of lending it meaning and direction. (Kinget, 1975, p. v, cited in Hergenhahn, 2008: 571).

\subsubsection{Maslow's Hierarchy of Needs}

In Third Force Psychology and the Study of Literature, Paris (1986:11-12) postulates that "Third Force psychology... offers a comprehensive view of human nature distinct from that of Freudians and behaviorists....It is Abraham Maslow, more than any other Third Force psychologist, who has attempted to determine what human beings require if they are to actualize their potentialities-or, to use the term he borrowed from Karen Horney, their 'real selves"'. Paris' book Third Force Psychology and the Study of Literature is regarded as the first collections of essays that applied humanistic psychology to literature. To stress the significance and the applicability of the humanistic psychology, Paris (1986: 61) has claimed that:

Third Force psychology is a powerful tool of critical, biological, and cultural analysis, the usefulness of which is just beginning to be properly appreciated. In literary criticism, it has been employed so far in their major ways: to analyze literary characters in motivational terms; to analyze the implied authors of individual works, showing their inner conflicts and blind spots; and to analyze the personality of the author as it can be influence of the reader's personality upon his critical response. The theory has many possible uses in the study of intellectual and cultural history, but these have been largely unexplored.

In his forward to Maslow's book Motivation and Personality, Robert Frager stated eloquently that: Abraham H. Maslow was a man who dared to listen deeply to himself and to his unwavering belief in the positive potential of the human species...Esquire's $50^{\text {th }}$ anniversary issue featured articles on the most important American figures of the mid-twentieth century. The editors chose Maslow as the most influential psychologist and also as one of the most important contributors to our modern view of human behavior. (Maslow xxxiv)

Summarizing Maslow's importance, Wilson (Cited in Colin Stanley, 2011) has declared that: 
Like all original thinkers, he has opened up a new way of seeing the universe. His ideas developed slowly and organically...; there are no breaks, or sudden changes of direction. His instinct is remarkably sound; none of his work has been disproved; none has had to be re-done...; in fact, I can see no single example in which he was definitely mistaken. He advanced with the faultless precision of a sleepwalker.

Maslow's theory of hierarchal needs is departed markedly from previous psychological works of Freudianism and Behaviorism who believe that human motivations and personality are formed either by only instincts or by a sole influence of the environment respectively. He criticizes Freudian and Behaviorist's error as "a hodgepodge of loose usage in which almost every known human reaction was characterized as instinctive." For Maslow, human motivations are caused by the combination of both instincts and environmental forces. In this regard, Maslow (Motivation and Personality, 1970: 11-48) clarified his thoughts saying that:

too many writers used the world instinct indiscriminately to cover need, aim, ability, behavior, perception, expression, value, and emotional concomitants, singly or in combination... Sound motivation theory must then take account of the situation, but must never become pure situation theory, that is, unless we are explicitly willing to give up our search for an understanding of the nature of the constancy of the organism in favor of understanding the world it lives in.

Maslow conceived his theory as a starting point for future research; it provided a testable theory of human motivation where "behavior is determined by several classes of determinants, of which motivation is one and environmental forces another". Therefore, he suggested that the Behaviorist paradigm is in accord with his theory of motivation, stating that "The study of motivation does not negate or deny the study of situational determinants, but rather supplements it. They both have their places in a larger structure."

By nature, each individual seeks to fulfill all of these needs, but at a given time he might concentrate upon the fulfillment of one of them. The higher needs emerge strongly when the lower needs are sufficiently satisfied. Hence, the individual's preoccupation will be centered first on the basic needs in the order of their prepotency. The emergence of the higher needs is not caused only by the fulfillment of the lower needs, but also by the maturity of the organism. The frustration of a basic need strengthens it and assures its perseverance. While satisfying it diminishes its strength as being a motivated force. Maslow believed that people whose lower needs were well satisfied early in life may develop a "frustration tolerance" that made them experience later deprivation without frequent regression. The regression of a person may be due to the sever deprivation of a lower need or due to the extended period of time.

However, this hierarchy of needs is not a mechanical or crude, since most behavior is multi-motivated. At any given instance there may be several or all of the basic needs at work with different power. It is better to notice that the satisfaction is not necessarily $100 \%$. In all their basic needs, individuals in society are partially satisfied and partially unsatisfied at any given time. The more individuals move up the hierarchy of prepotency, the more satisfaction percentage is decreased. Under the good and favorable conditions, the individuals may have experience higher need motivations. Whereas under unfavorable conditions the individuals' needs are suffered from regression to the lower level. That refers to the fact that: "Behavior is not solely determined by inner needs; the cultural setting and the immediate situation are also important determinants. The hierarchy of prepotency will determine what we want, but not necessarily how we will act" (Paris, 1974).

Maslow's theory of human needs is a theory of individual personality formations, believing in the potentiality of all humans to reach their self-actualization and individuality as a natural healthy psychological growth. Based on survival value, his theory shows that human basic needs move on in ascending tiers of priority or potency, directing towards achieving that growth in the process. If these needs are persistently not met and they are frustrated, psychological problems may arise. Maslow proposes that when each tier is gratified, the other one will clamor for satisfaction. His theory emphasizes that this hierarchal is a natural or innate characteristic of human life, for people almost always desire for something.

Moreover, Maslow's theory stems from a notion that human beings share common and universal desires (i.e. motivation), although they might differ in their means to satisfy these desires according to the cultural differences. To clarify the universality of these desires, despite their means fulfillment, Maslow gives an example about obtaining self-esteem, saying that in a culture, it is believed that a good hunting might satisfy this need as it gives the individual the esteem and respect he seeks, while in another culture a healing might successfully fulfill this desire. Yet, achieving the same goal via different cultural paths never classifies individuals differently, for in the essence it is revolving around the same dynamic center or aim which is 
satisfying the desires for human survival. "Human beings are more alike than one would think at first," Maslow (1987:6) states.

Hence, as a case in point, Machiavelli believes that the survival of the prince and achieving the esteem he wishes may come from the prince ability to be a lion and fox at the same time, to have the full control over his people by adopting different means, for as mentioned previously, Machiavelli believes that the end justifies the means. Maslow, however, indicates that the human desires have a very significant common feature, which is that they are not an end by themselves; rather they are usually means to an end. That is to say, the most important point is to analyze the desires' meanings, what they stand for, and where they lead. Such deeper analysis implies a central place for the unconscious life in motivating human desires.

Furthermore, Maslow stresses that each desire has conscious and unconscious levels, hence any motivated action whether 'preparatory' or 'consummatory' might serve as a kind of channel through which many basic needs may be simultaneously expressed or satisfied. Therefore, Maslow prefers not to list specificity of the motivation, as they are overlapped and interrelated. For instance, respect and love desires may underline complex unconscious purposes. In one individual such desire means proving his masculinity or her femininity, for other it fundamentally reflects their individuality, friendship, sexuality, status or combination of them. Nevertheless, Maslow points out that the satisfactions of human needs are relative, not mandatory complete ones.

Maslow's theory of motivation involves five basic needs that motivate human behavior. In ascending order these needs include:

1- Physiological needs: they are the lowest and the basic needs in Maslow's hierarchy. They include the need for water to drink, food, sleep, activity, clothing and shelter

2-Safety needs: these needs are related with economic security, law, order, and security of the family, of health and of property.

3- Belongingness and Love needs: these needs may include friendship, belonging to a group and giving and receiving love.

4-Esteem needs: these needs might be external or internal. Esteem needs that are internally motivated are those such as self-esteem, accomplishment, and self respect. Whereas, external esteem needs are those related with the reputation recognition and respect by others.

5-Self-Actualization needs: these needs are never fully satisfied; as individual grows psychologically there will be always new opportunities to continue to grow. The motivators for these needs may include justice, truth, wisdom, morality creativity .

These needs are the determinants and motivators of human behavior and they are classified according to the specific goals. It is noted that though Maslow presents five needs, the top level is his main target. The first four levels are the most determinants of the human's motivated behavior directing towards certain goals, while the last level is a goal by itself, as it is regarded an epitome resulted from satisfactions of previous desires. Maslow's theory of motivation espouses a dualistic view as he divides his hierarchal into two strata, the first has the four basic needs which he called them "deficiency motives, D- motives", and the fifth stratum is the "growth motives, being motives, or B-motives." In the latter motives or desires, the need for self-actualization is rested as independent one. However, the former motives or desires which are possessed by everyone are selfpreservation and almost they are indispensable.

The emergence of a higher need reveals the standard of psychological health. The satisfaction of a need is greatly valued by the individuals, whom upon reaching this stage, will not prefer and appreciate the lower needs. Yet, the higher needs are not as urgent as the lower needs which are connected with survival. Nevertheless, if an individual's satisfaction of the lower needs is crippled by any block, it will be difficult for him or her to reach the top of pyramid. This postulates a notion that to become fully a human, a hierarchy of basic needs must be regularly satisfied. However, what self-actualization involves is "a fuller knowledge of, and acceptance of, the person's own intrinsic nature" and "an unceasing trend toward unity, integration or synergy within the person" (Maslow, 1987: 22).

If the B-values, that Maslow posits and which he feels dominated the lives of self-actualizing individuals, are not given the chance to express themselves and the individuals are blocked striving in previous levels, those deprived individuals will show certain characteristics that are intersecting with some characteristics of Machiavellian personality, and as shown below:

\begin{tabular}{|l|l|l|l|}
\hline & $\begin{array}{l}\text { B- } \\
\text { Values }\end{array}$ & Deprivation of these values causes & \multicolumn{1}{|c|}{ Machiavellian personality } \\
\hline 1 & Truth & $\begin{array}{l}\text { Dishonesty, mistrust others, cynicism; } \\
\text { skepticism, suspicion }\end{array}$ & $\begin{array}{l}\text { Deceive, lie, cynicism, "Men are so simple of } \\
\text { mind, and so much dominated by their } \\
\text { immediate needs, that a deceitful man will } \\
\text { always find plenty who are ready to be }\end{array}$ \\
\hline
\end{tabular}


“Just try to see it human, see it human": A Humanistic Psychological Reading to the Machiavellian

\begin{tabular}{|c|c|c|c|}
\hline & & & deceived." \\
\hline 2 & $\begin{array}{l}\text { Goodnes } \\
\mathrm{s}\end{array}$ & Evil, selfishness, hatred & $\begin{array}{l}\text { Immorality, self-interest," "...it is necessary } \\
\text { to a prince, wanting to maintain himself, to } \\
\text { learn how to be able to not be good and to use } \\
\text { this and not use this according to necessity". } \\
\text {-Machiavelli }\end{array}$ \\
\hline 3 & Beauty & $\begin{array}{l}\text { Ugliness, restlessness, loss of taste, } \\
\text { tension. }\end{array}$ & $\begin{array}{l}\text { Emotional coldness, duplicity, " } \\
\text { "....it is necessary to a prince, wanting to } \\
\text { maintain himself, to learn how to be able to } \\
\text { not be good and to use this and not use this } \\
\text { according to necessity”. Machiavelli }\end{array}$ \\
\hline 4 & $\begin{array}{l}\text { Justice } \\
\text { and } \\
\text { order }\end{array}$ & $\begin{array}{l}\text { Injustice, insecurity, cynicism, mistrust, } \\
\text { chaos }\end{array}$ & $\begin{array}{l}\text { Manipulating, aggressiveness, exploiting } \\
\text { others, regardless of the consequences } \\
\text { concerning the exploited, low ideological } \\
\text { commitment, "When the states that one } \\
\text { acquires are used to living with their laws and } \\
\text { liberty, there are three ways to keep them; the } \\
\text { first, ruin them... because in truth, there is no } \\
\text { way to possess them other than ruin." } \\
\text { "...the nature of peoples is variable; and it is } \\
\text { easy to persuade them of something, but it is } \\
\text { difficult fix them in it. Therefore it is } \\
\text { necessary to be prepared so that, when they } \\
\text { no longer believe, one might make them } \\
\text { believe by force" } \\
\text { Machiavelli }\end{array}$ \\
\hline 5 & Order & Breakdown of authority, chaos & $\begin{array}{l}\text { Manipulating, aggressiveness, exploiting } \\
\text { others, regardless of the consequences } \\
\text { concerning the exploited. "...it is necessary to } \\
\text { a prince, wanting to maintain himself, to learn } \\
\text { how to be able to not be good and to use this } \\
\text { and not use this according to necessity". - } \\
\text { Machiavelli }\end{array}$ \\
\hline
\end{tabular}

It is not an easy to understand the amount of evil in our world, in human history and within ourselves. Maslow concludes that the bad social institutions, ignorance, the illness of personality, are some reasons for creating evil, irresponsible individuals. He maintains that evil can be diminished by satisfying individuals' needs by "health and by therapy, by knowledge and wisdom, by chronological and psychological maturity, by good political, economic, and other social institutions and systems" (Maslow, 82).

\subsection{Horneyan Theory of Basic Anxiety:}

Regarded as one of the most prolific psychologists in the twentieth century, Karen Horney (18851952) presents theories that concentrate on self and neurotic aspects of behaviors, their causes, and their strategies (Paris, 1994:2). Horney's work has received a lot of attention as it provides researchers in different fields, including literature, with a number of fascinating insights and provocative concepts that help to analysis human personality. Maslow admits the significance of her works. In this regard, the critic Bernard J. Paris ${ }^{1}$ (1996:213-214) states his belief that Maslow owes a lot to Horney's theory and that he is one of the "subsequent theorists" who developed Horney's psychological concepts:

Horney devoted most of her attention to analyzing the defenses we employ to cope with frustration and threat. It remained for subsequent theorists to elaborate her vision of optimal development...Abraham Maslow focused on self-actualization, providing a fuller picture than [Horney] of our basic motivations and the nature of psychological health. Maslow drew on the work of many others as well, whom he described as belonging to the "Third Force" in modern psychology. Horney was a seminal figure in this group, 
and it is to Third Force psychology that her mature theory most clearly belongs.

Horney and Maslow emphasize the primacy significance of fulfilling one's potential. She points out in her book Neurosis and Human Growth (1950:17) that "the human individual...tends to develop his particular human potentialities. He will develop then the unique alive forces of his real self he will grow... toward self-realization." In depicting Maslow and Horney's contribution to the development of psychology, Paris (2010:28) maintains that "Healthy growth is a process of actualizing... self and neurotic development is a process of becoming alienated from it.... Abraham Maslow is the greatest student of self-actualization, and Karen Horney offers the most systematic account of self-alienation." Estimating that the psychologies of Maslow and Horney share common conceptual foundations, Paris (2010:28) also characterizes Horney's concepts in terms of Maslow's hierarchy of needs. In his perspective, Horney "is concerned, in particular, with what happens to people when they are deprived of their needs for safety, love and belonging, and esteem, the middle needs on the Maslovian hierarchy."

In analyzing Horney's psychological theory, Paris acknowledges three stages. He suggests that Horney started as one of the Freudian proponent, and then she expresses her rejection to some of Freudian's concepts especially that is related to women's issues of penis envy and feminine masochism. This stage has led her to investigate the influence and the importance of culture and interpersonal relationships on neurosis. In her third stage, which Paris describes as 'the mature stage', she has published a series of books like The Neurotic Personality of Our Time (1937), New Ways in Psychoanalysis (1939), Our Inner Conflicts (1945) and Neurosis and Human Growth (1950) where she stresses largely on the effects of cultural and social factors in the development of human relationship and personality, opposing in this, Freud's concepts of the instinctual urges satisfaction, especially sexual urges. In her mature stage, Horney uncoveres her belief that people try their best to "cope with the anxiety produced by feeling unsafe, unloved and unvalued by disowning . . . spontaneous feelings and developing elaborate strategies of defense" (Cited in Kimble and Wertheimer, 2000: 163).

Moreover, Horney's importance lies within the fact that her theory emphasizes individual's current situation rather than merely the past, leading to address the current defenses and inner conflict. Like Freud, Horney indicates that man's inner conflict and problem originating in early childhood, yet she does not restrict the adult to his earlier pattern and she does not attribute his current state merely to the childhood experience. When children adopt certain defensive strategies, their character structure develops as a result of external and internal factors that might encourage some strategies and discourage others. That makes her theories be applicable and especially appropriate for the analysis of literary characters. Hence the character structure finds its basis in early childhood, but it is molded by "a complicated evolutionary history". Furthermore, Horney's theories answer the shortcomings of psychoanalytic study of character that needs a portrayal of childhood experience to account for the behavior of adult. Since in literature, especially in drama, such an experience is very rarely presented, the application of Horney's theories that focus more on adult existing defenses and their inner conflicts provide the researcher a great deal of information and a suitable means to analyze the characters' inner conflict in recognizable way (Paris, 2009:18).

Horney assumes that neurosis is a distortion process of normal human needs. She criticizes Freud for his emanating psychological anxiety and neuroses to the biological or instinctual causes and for "his habitual failure to take cultural factors into consideration" (Horney, 1939: p. 98). It is worth to mention that there is no clear demarcated between neurotics and normal people. The needs that normal people strive for are the same that of neurotics but the needs for the latter are more excessive, and exaggerated. Horney's theory is more culturally based, defining the basic anxiety as a feeling of being 'isolated and helpless toward a world conceived as potentially hostile" (p. 18) and ascribing the anxiety, and the neurotic trends to cope with that feeling, to the lack of "favorable conditions for growth" (p. 13) requiring "an atmosphere of warmth" (p. 18) along with the "goodwill of others" (p. 18) and "healthy friction" (p. 18) with others. She critically criticizes Western cultures assuming that "among the factors in western civilization which engender potential hostility, the fact that this culture is built on individual competitiveness probably ranks first" (Horney, 1939: p. 173). For Horney, "the problem of the influence of cultural conditions in creating neurotic conflicts is far more complex than Freud sees it" (p. 177).

Homey sees the process of self-realization is a sign of healthy human development, while selfalienation is unhealthy development. By relative meeting of his needs, the individual develops "the clarity and depth of his own feelings, thoughts, wishes, interests ....; the special capacities or gifts he may have; the faculty to express himself, and to relate himself to others with his spontaneous feelings... [and] to find his set of values and his aims in life" (Horney, 1950:17). Psychologically speaking, the thwarted needs make individual develop in a quite different way. According to Homey, self-alienation becomes a strategy of defense against "basic anxiety," which is a "profound insecurity and vague apprehensiveness" (Horney,1950: 18) created by feelings of isolation, helplessness, fear, and hostility. Due to the effect of the 
anxiety, the child "cannot simply like or dislike, trust or distrust, express his wishes or protest against those of another, but he has automatically to devise ways to cope with people and to manipulate them with minimum damage to himself" (Horney,1945: 219). To cope with his hostile environment and to seek compensate for the feelings of worthlessness and inadequacy, the individual develops the interpersonal strategies of defense and an intrapsychic process of self-glorification. These strategies, mainly, comprise his effort to fulfill his frustrated needs for safety, love and belonging, and self-esteem as well as to reduce his anxiety and to provide a safe outlet for his hostility.

\subsubsection{Interpersonal Strategies}

Horney delineates that to overcome the feeling of unsafe and unvalued in this hostile world; people apply three strategies of defense. They move toward others in self-effacement; they move against others in expansion, striving for dominance, power, prestige and glory; as well as, they move away from others, in resignation, seeking detachment. Normal or mature people are capable of expressing and balancing the three strategies, which experience in all human relation. Yet, some individuals who cannot conquer the basic anxiety of their circumstances, they adopt and adhere rigidly to one of the fundamental modes at the expense of the others, to which it becomes their only "solution" to neurotic conflict (Horney, 1950).

An individual whose primary style is one of self-effacement or compliance grows up "under the shadow' of someone else, like a preferred sibling or a parent who demanded utter devotion (Horney, 1950). In the self-effacing strategy, called "moving toward people" seems to say, "if I give in, I shall not be hurt" (Horney, 1937:83):

In sum, this type needs to be liked, wanted, desired, loved; to feel accepted, welcomed, approved of, appreciated; to be needed, to be of importance to others, especially to one particular person; to be helped, protected, taken care of, guided (Horney, 1945:51).

So, the individuals of this personality attempt to compensate for feelings of inadequacy by gaining the affection of others, trying to avoid the anger of others by repressing and disguising their own needs and rage. Their considerate, appreciative, responsive, understanding and sensitive to the needs of others might seem unusual and abnormal. They live up, accordingly, to meet others ideals and expectations. Never being assertive, critical or demanding, the complaint individual seems weak and helplessness. He looks down to himself, regarding others as superiors. Horney points out that the individual of complaint personality "accepts his own helplessness, in spite of his estrangement and fears tries to win the affection of others and to lean on them (Horney, 1945:42)

This personality, moreover, identifies any striving as "a dangerous or reckless challenging of fate" (Horney Neurotic and Human Growth 218). Related his being to others' attitude and behaviors, he excessively needs their constant approval and reassurance. Horney, significantly, believes these exaggerated traits of goodness, sympathy, love, generosity, unselfishness, and humility are superficial and originally based on repressed aggressiveness, feelings of hostility, egotism, ambition, heartlessness, immorality and manipulation of power (Horney,p.54). Having repressed his hostile impulses, complaint personality turns to be subservient, looking forwards to satisfying others neglecting their own desires. Paris points out that such personality embraces Christian values for they provide them with a necessary system of defense. The individual's "bargain is that if he is a peaceful, loving person who shuns pride and does not seek his own gain or glory, he will be well-treated by fate and by other people. If his bargain is not honored, he may despair of divine justice, he may conclude that he is the guilty party, or he may have recourse to belief in a justice that transcends human understanding" (Paris, 2009: 21).

The other personality defense used to cope with anxiety is the aggressive or hostile personality that moves against people. This personality believes in the survival of the fittest. Life is a jungle where the strongest eats the weakest and where "the strength, and ferocity are the paramount virtue." (Schultz and Schultz, 2008:165). Consequently, for this personality "the appeal of life lies in its mastery. It chiefly entails his determination...to overcome every obstacle-in or outside himself-and the belief that he should be able, and in fact is able, to do so" (Horney, 1950:192). Horney explains that the individual who holds strategies of selfexpansive gravitates around domination. Such individual is overwhelmed by a shamed suffering as he needs "to achieve success, prestige, or recognition" (Horney, 1945: 65):

Any situation or relationship is looked at from the standpoint of "What can I get out of it?"-whether it has to do with money, prestige, contacts, or ideas. The person himself is consciously or semiconsciously convinced that everyone acts this way, and so what counts is to do it more efficiently than rest. 
This hostile type may act politely and friendly, but it is always a means to an end (Olson and Hergenhahn, 2011:133). Horney itemizes three types of aggression connected to this personality which are narcissistic, perfectionist, and arrogant-vindictive. These behavioral tendencies differ from each other, yet they stem from the same desire to elevate the self, thereby confronting internal insecurities. The narcissistic personality tends to dominate and control fate by "self-admiration and the exercise of charm" (Horney, 1950: 212). Horney defines narcissism as simply "self-inflation" meaning that the narcissist "loves and admires himself for values for which there is no adequate foundation" (Horney, 1939: 90). Horney suggests that the individual embracing this type of behavior resembles a spoiled child who grows up seeing himself the favorite of fate, "the anointed, the man of destiny...the benefactor of mankind" (Horney,1950: 194; Paris, 2009:110 ). However, in their careers, narcissists' working style is described as superficial and unproductive, combined with increasing entitlement or the "expectation that devotion or glory can be obtained without effort and initiative" (Horney, 1939: 95). Narcissists seek a kind of relationships that add to their status and prestige. Their highly unrealistic view of themselves leads them to manipulate other people as admiring audiences and supporters. Having difficulty finding people who continue to do so, the narcissists become constantly in a state of alienation from the self and others.

On the other hand, the perfectionist personality also creates an exaggerated estimation of the self so that to compensate for feelings of insufficiency. This individual sets extremely high moral or intellectual standards in order to feel superior to others. Perfectionists externalize their failures, constantly finding others stupid and immoral and generally fault. Having such high standards can give these people a feeling of mastery, but because they can tolerate no imperfection, they may release self-hate if they are forced to admit their own faults. The perfectionist tends "to equate... knowing about moral values and being a good person" (Horney, 1950: 196). His expression of the littleness of others projects their own fears of inferiority and insecurity. He aims for a "flawless excellence [in] the whole conduct of life" (Horney 1950: 196).

Finally the arrogant-vindictive personality is motivated by a need for vindictive triumph over others (Paris, 2009: 22). Horney suggests that individuals with this behavioral may have been harshly treated as children and need to strike back for harms they have suffered (Horney, 1950: 221). Such individuals avoid emotional attachment and attempt to exploit others in order to heighten their feelings of mastery. They inherent moral law by which the universe operates, according to the arrogant-vindictive person, is that 'might makes right" (Paris, 2009: 23). Such individuals are hyper-competitive, cynical and ruthless in their relations with others.

According to Horney (1937, 188-206) hypercompetitive orientation is indiscriminately a need to compete and win and to avoid losing at any cost. Hypercompetitiveness is typically a consequence of disturbed parent-child relationships where children were verbally and physically abused by their parents. So, hypercompetitiveness is a means to enhance one's feelings of self-worth. Moreover, hypercompetitive individuals are also involved in the feelings and thoughts of manipulation, aggressiveness, exploitation, and cheating of others across a many situations. Furthermore, hypercompititive individuals make their aims in life be the seeking for self-aggrandizement and the strife for personal superiority in virtually all fields, let them perceive others as malevolent and distrustful. In their self-defeating quest for superiority, they show tendencies to be hostile, rigid, conceited, aggressive, and decisive towards others. To prove their unique superiority in their sexual life, these individuals greatly attempt to subdue and humiliate their partners.

Horney believes that such an exaggerated competitive attitude was a central feature of American Culture. It is "a problem for everyone in our culture" (Horney, 1937:188) and has a highly destructive and negative impact on the individual's development and functioning as it spreads into personal relationship:

Our modern culture is economically based on the principle of individual competition, [and] the...individual has to fight with other individuals of the same group, has to surpass them and, frequently, [to] thrust them aside. The psychic result...is a diffuse hostile tension between individuals. [This] competitiveness, and the... hostility that accompanies it, pervades all human relationships. It pervades the relationships between men and men, between women and women, and whether the point of competition be popularity, competence, attractiveness, or any social value, it greatly impairs the possibilities of reliable friendship...[C]ompetitive stimuli are active from the cradle to the grave [and present] a fertile ground for the development of neurosis.

(Horney, 1937:284)

Horney also thinks that there is a positive link between the aggressive attitude of hypercompetitiveness and Machiavellianism. Generally, Machiavellians have an aversion towards others and use means like lying and deceit to successfully manipulate them (Christie \& Geis, 1970, p. 3). Similarly, Horney noted that hypercompetitive and aggressive individuals fundamentally dislike others but their attitudes are often "covered over with a veneer of suave 
politeness, fair-mindedness, and good fellowship" (Horey 1945, 63). This "front" represents "a Machiavellian concession to expediency" (Horey 1945, 63), as he is "extremely proud .. of his faculty of fooling everybody" (Homey 1950, 193). Such individual tries direct and indirect ways to exert control over others and exploit them.

In addition to self-effacement and self-expansion, Horney delineates a third solution or strategy of resolving inner conflicts which is "resignation." In Horny (1950: 259) conception this type of strategy with its orientation of moving 'away from' people, consists of "withdrawing from the inner battlefield and declaring himself uninterested. As a result of inner conflicts, Horney suggests, the individuals may follow a "principle of nonparticipation" (264), expressed as "detachment," and an "emotional distance from others" (264). In moving "away from" people, the individuals "want... neither to belong nor to fight, but keep... apart" (43).

What is crucial is their inner need to put emotional distance between themselves and others. Moreover accurately, it is their conscious and unconscious determination not to get emotionally involved with others in any way, whether in love, fight, co-operation, or completion. They draw around themselves a kind of magic circle which no one may penetrate. (Horney, 1954:75)

This personality, moreover, has a "hypersensitivity to influence, pressure, coercion or ties of any kind" (Horney 1950:266, emphasis in the original). The individual tends to avoid any anxiety to physical pressure from clothing, closed space, long-term obligations such as marriage or conventional values and behaviors. His need for superiority is not like that of aggressive personality. The detached individual, due to his inability to compete with others, believes that his greatness and superiority have to be approved automatically without any effort from his part. Hence, his desires and ambition realizes only in imagination. Moreover, this personality cultivates a "don't care" attitude and protects himself against any frustration by thinking that "nothing matters" (Paris, 1997:28).

Horney's description of experiences is typical for those who conduct each of these solutions (strategies), but most individuals develop a combination of these experiences and self-defenses. However, a conflict between these strategies results in self-hate and fluctuation. Paris (1997:30) explains that the result of such conflict is one of the significant features of Horneyan theory as it "permits us to make sense of contradictory attitudes, behaviors, and beliefs by seeing them as part of inner conflicts." The conflicts between interpersonal strategies or solutions, of moving toward, against and away from people that individual applies when he finds himself in an anxiety situation, are associated with intrapsychic problems which also have their own strategies.

\subsubsection{Intrapsychological Strategies}

Horney's emphasis on culture and interpersonal conflict does not mean that she underestimates or neglects the role of intrapsychological factors in the development of human personality. She also believes that intrapsychic conflicts are experienced by both normal and neurotic individuals. It is worth to mention Horney (1950: p. 237)asserts her rejection to "a one-sided focus on either intrapsychic or interpersonal factors," stating that the dynamics of neurosis can be recognized "only as a process in which interpersonal conflicts lead to a peculiar intrapsychic configuration, and this in turn depends on and modifies the old patterns of human relations". Although she sometimes overemphasizes the intrapsychic herself, her theory as a whole maintained the balance she prescribed.

Basically intrapsychic strategies or conflicts originate from interpersonal experiences "from [individual] earlier fantasies, his particular needs, and also his given faculties" (Horney, 1950: 22). As intrapsychic strategies develop to be part of individual's belief system, they create their own entity, separating themselves from the interpersonal strategies or conflicts that gave them an existence. Under intrapsychic strategies, Horney discusses the formation of idealized self created by the aid of individual's imagination to compensate for his feelings of self-hate, inadequacy and to endow him "with unlimited powers and with exalted faculties" Horney, 1950:22).

Horney differentiates between different selves which are the real self, idealized self, actual self and despised self. However, the individual extensive conflicts arise when the idealized self is apart from real-self. The idealized self, in turn, generates the pride system, neurotic claims and tyrannical of 'shoulds' that increase individual self-hate. For Horney (1950:17), the real self is "a central inner force, common to all human beings and yet unique in each, which is the deep source of growth" and it is the one that involves in the healthy psychological growth. It is the real self that develops if individual has been nurtured in proper conditions. Horney (1950:17) states in this respect that the human individual... will develop then the clarity and depth of his own feelings, thoughts, wishes, interests; the ability to tap his own resources, the strength of his will power... the faculty to express himself and to relate himself to others with his spontaneous feelings.... In short, he will grow substantially undiverted toward self-realization.

The concept of the real self constitutes a fundamental foundation of the psychologies of Horney and Maslow. Horney (1050: 13) asserts that "Under favorable conditions man's energies are put into the realization of his own potentialities... wherever his course takes him, it will be his given potentialities which he develops." 
Her insistence on the significance of the realization of one's potential vibrates with Maslow's notion of selfactualization.

Just as the favorable environmental conditions make a healthy real-self, so the unfavorable environmental conditions weaken the realistic inner confidence of individual and force him to develop certain defenses which in return direct all his energies to compensate for feeling unsafe and to unify the personality. Consequently, all the attempts to develop his real self are overridden to the extent that he feels no longer the master of his destiny and he is driven by his needs that alienate him more from his real self. This alienation causes individual to seek a sense of stability, identity and worthiness by creating an idealized image that replaces the real self and which provides him an avenue for dealing with his conflicts. It is worth to mention that the individual alienation is from his real-self not from his actual self, a term that Horney offers to refer to everything the individual really is at a given time.

The idealized self image may take different forms according to the predominant solution or strategies the individual adopts. So the idealized self image by its nature contains contradictory aspects where individual strives to actualize. The idealized self image of self-effacing individual "is a composite of 'lovable' qualities, such as unselfishness, goodness, generosity, humility, saintliness, nobility, sympathy" (Horney 1950, 222). Whereas, arrogant-vindictive individual sees himself as masters of all situations who is smarter, tougher, more realistic than other people, narcissist sees himself as godlike and supporter of mankind who has unlimited potentialities and is capable of splendid achievements, naturally attained. On the other hand, perfectionist considers himself as a model of righteousness, who never makes any fault in the whole conduct of life. The idealized image of detached or resigned individual "is a composite of self-sufficiency, independence, selfcontained serenity, freedom from desires" and "stoicism" (277).

Horney states that the idealized self may generate "the search for glory" (24), in which "selfidealization remains its nuclear part" (24), "neurotic pride" which is "the climax and consolidation of the process initiated with the search for glory" $(1950,109)$ and "neurotic pride". In the process of the idealized image formation, the individual embarks upon a "search for glory," as "the energies driving toward selfrealization are shifted to the aim of actualizing the idealized self" (Horney 1950, 24). Self glorification gives feelings of superiority and importance to compensate for the actual feelings of fear and lack of acceptance and to justify the idealized self. Horney explains that the search for glory and the need to be god-like figure is not really an" essential ingredients of human nature but as reactions to the frustration of basic needs" (Paris, 1977: $31)$.

Man, however, is always in search for something beyond himself; but the normal human being seeks "realistic supremacy" and works with his limitation and potentialities. If happened that he failed, he accepts his frustration without self-hate or despair. For the neurotic individual, the search for glory is preoccupied him as he epitomizes all his life in his glorification self; he is either all or he is devastated. This individual clings to the idealized self for glorification because it gives him a sense of meaning and feeling of superiority he so desperately longs for. He may experience depression or despair if he feels that his search for glory will be failed. He severely counters all infringements on their illusory magnificence and may prefer death to the shattering of his dreams. The search for glory, Paris (1997: 32) maintains, is a prominent feature of every culture as well as a unique one in each individual. The glory systems comprise various forms of group identification, religious and materialistic, like, Christ figure, wars and military service, and competitions, and honors.

The glorified self leads individual to self hate as a result of choosing the idealized self over the real self. In this respect Horney (1950: 110) writes:

The glorified self becomes not only a phantom to be pursued; it also becomes a measuring rod with which to measure his actual being. And this actual being is such an embarrassing sight when viewed from the perspective of god-like perfection that he cannot but despise it. Moreover, what is dynamically more important, the human being which he actually is keeps interfering-significantly-with his flight to glory, and therefore he is bound to hate it, to hate himself.

The search for glory, moreover, has three other elements, beside self-idealization: the need for perfection, neurotic ambition, and the drive toward a vindictive triumph. Achieving glory through perfection aims at molding the whole personality into the idealized self. Accordingly, neurotic individual is not content to merely a simple change; rather he tries to remodel himself into a "special kind of perfection prescribed by the specific features of his idealized image" (Horney, 1950:25). He tries to achieve his glorified perfection by a complex system of "shoulds" and "should nots". Horney refers to this system as the "tyranny of should" through which the individual unconsciously and relentlessly strives toward an imaginary image of perfection, convincing himself that "forget about the disgraceful creature you actually are; this is how you should be (Horney, 1950: 64). 
A second element in the search for glory is neurotic ambition, which Horney (1950: 26) describes as the compulsive drive toward superiority and external success which has little relation to the content of what one is doing. What counts more is the excelling itself. In general this is either in the category of power (direct power, power behind the throne; influence, manipulating) or the category of prestige (reputation, acclaim; popularity, admiration; special attention). The third key aspect of the search for glory is the drive toward a vindictive triumph. This drive is very destructive as it may disguise itself in the dress of achievement and success, but "its chief aim is to put others to shame or defeat them through one's very success; or to attain the power, by rising to prominence, to inflict suffering upon them- mostly of a humiliating kind" (Horney, 1950: 27). The drive for a vindictive triumph stems from childhood impulses to take revenge from real or imagined humiliations. No matter how much success the neurotic individual fulfills over others, the drive for a vindictive triumph is never extinguished; instead it is increased with each victory.

In addition to the search for glory, the idealized image produces a structure of phenomena that Horney calls "the pride system." The neurotic individual takes pride in the imagined attributes of his idealized self and accordingly this pride makes "neurotic claims" on others. Pride system is composed of two phenomena that inevitably accompany each other; neurotic pride and self-hate. It is false pride where attempts made to substitute for realistic self-confidence and self-esteem- such as being more intelligent, stronger or respected than everyone else. On the other hand, neurotic pride is invested in the idealized self-image and is loudly proclaimed in order to support and protect a glorified view of individual's self. Neurotic pride, says Horney (1950: 109), is "the climax and consolidation of the process initiated with the search for glory." Neurotics count a lot on their imagination, turning their compulsive behaviors of the various solutions into merits; for them anything becomes a source of pride. Moreover, the mental processes of imagination, which has an infinite power, are working at "maintaining the private fictitious world through rationalizations, justifications, externalizations, reconciling irreconcilables--in short, through finding ways to make things appear different from what they are" (Horney, 1950: 91-94).

Nevertheless, pride is an essentially important defense, but being based on illusion and self-deception, it increases our defenselessness. When the neurotic feels that others fail to treat him with special consideration, his neurotic pride is collapsed, producing deep anxiety and hostility; and resulting in self-contempt. He becomes a subject to feelings of shame (the violation of his own pride) and humiliation (his pride is violated by others). The constant failure of the actual self to live up to the imagined self makes individual react to shame with selfhate or self-criticism and to humiliation with a vindictive hostility ranging "from irritability, to anger, to a blind murderous rage" (Horney 1950: 99).

The need to actualize the idealized image leads individual to make severe demands or taboos, a phenomenon Horney calls "the tyranny of the should":

Forget about the disgraceful creature you actually are; this is how you should be; and to be this idealized self is all that matters. You should be able to endure everything, to understand everything, to like everybody, to be always productive- to mention only a few of these inner dictates. Since they are inexorable, I call them "the tyranny of should." (1950:64-65)

Like other defending, the shoulds are a defense against despised self as well as they worsen the condition they are used to solve. However, these shoulds increase one's self-alienation and intensify self hate, because the result of any failure is a feeling of worthlessness and self-contempt. Hence, the should has such a tyrannical power. "It is the threat of a punitive self-hate" that "truly makes them a regime of terror" (Horney, 1950:85). Shoulds refer also to the rules, commands, and authorizations that unconsciously living within oneself. Inescapably, they tell neurotic what he "should be able to do, to be, to feel... (to) understand, and (to) foresee everything To know-and taboos on how and what he should not be" (Horney, 1950:65-68).

The shoulds are characterized by their inflexibility, impregnability to psychic laws, as well as their dependence on will- power for realization and on imagination for denial of failure. Essentially, these should reflect the demands, wishes and needs that are not easy to be repressed. The neurotic may say, I should love everyone and everyone should love me; I should never make a mistake; I should always triumph; I should be able to get away with anything, I should be successful and so forth. Because the should are unrealistic, they are impossible to live up to, reflecting our inner conflicts as they are in sever confrontation with each other. Generated by the idealized image which is a composite of various solutions, the shoulds are often "caught in crossfire of conflicting" and clashing of inner dictates. That, moreover, causes an intensifying hate of one's self (Paris, 2010: xv). 


\section{IV "I am in business, a man is in business": Keller's Psychological Journey from an Illusory Success to a Real Death}

"Some of the greatest insights into human personality have come, not from the discipline of psychology, but from the humanities, art, etc.... Miller can in a sense be called a 'personality psychologist' because of the many insights he presents which parallel particularly contemporary humanistic psychology" (Evans, 1969 121).

In the above quotation, Richard I. Evans (1969) singles out Miller's drama as a superb representation of human personality. In his book Psychology and Arthur Miller, Evans (1969) explains, in an interview with Arthur Miller, that the dramatis' plays, particularly All my Sons and A Death of a Salesman are truthful characterization of common man who lives under daily economic strains and who consequently suffers from some psychological problems. This man, produced by war experience and the Depression period, becomes a victim to relentless competition where business career is based on survival through materialistic aspirations devoid of moral consideration.

Arthur Miller's world-view, as portrayed in dramatic realistic situations taken from a real life, is based on questioning the "right and wrong", and on his speculation on the nature of serious drama that it has to show "how and in what way must [a man] strive to change and overcome within himself and outside himself if he is to find the safety, the surrounding of love, the ease of soul, the sense of identity and honor...?" (public issues,p6667). In addition, his dramatic characterization demonstrates a psychological view of what makes a person human. Similar to the main thoughts of the Third Force Theory, Miller rejects restraining human beings to merely biological or environmental drives, like sex, hunger or fear. Moreover, in a meeting with psychologists at the American Psychological Association, Miller negatively reacts to the behaviorists' mechanical view to control man's behavior, believing that behaviorists have failed to reveal and mirror the humanistic compassion for man. He states that "there is ... a countervailing impulse, an impulse toward changing [man's] environment in order to enhance life... Perhaps a possible definition that what makes a person human is the conflict in him between the forces of life and death" (Richard Evans,88-89). In a sense, Miller seems echo both Maslow in his stress on the psychological importance of the social and ethical impulses in creating a full human being and Horney in his postulating that the "fundamental tension.....in our time" comes from the uncertainty as "to whether we are....the representative of an interest, of a concealed or open social necessity." He, like Horney, observes the contradictions of his society that try on one hand to rationalize the society and make it efficient, and on the other hand they extol the individual, emphasizing the competitiveness and the significance of the economic aspect in recognizing that individual. (Richard I Evans, 89).

In analyzing the Machiavellianism of Arthur's businessmen, the researcher aims at understanding the characters needs, anxieties, their defenses and objectives in life, so that to grasp their emotional needs and to imaginatively penetrate their experiences in life. In understanding them empathically as normal people, one can see that they are disturbed, destructive, but they are suffered human beings.

One of the important points that Bernard Paris explains in his application of the humanistic theory in literature is that the characters of a literary work, though they are factious, have to be realistic or have human realistic behaviors so that they will be treated as human beings, in one way or another. Arthur Miller's All My Sons is said that it is based on a real incident of a daughter of a manufacturer in the United States who has reported the authorities after her discovering that her father had sold defective machinery to the army during the war. Miller in this play explores the changes that the World War II brought to America. He describes the pervasiveness of these changes that affected the way that people thought, their quest for fulfilling their American dream, their economic statues, and the way of pursuing the materialistic needs to cope with the developmental and technological life.

The Depression loomed large in the imagination of Arthur Miller in a manner that is hard to overstate. A period that saw Miller's father's failure in business and the consequent rapid downward spiral of his immediate family, Miller wrote that the Depression "was only incidentally a matter of money. Rather it was a moral catastrophe, a violent revelation of the hypocrisies behind the façade of American society" (Timebends 144).

In order to establish a successful business, which means everything to him, Keller is willing to lie, cheat, manipulate his friend, sending him to jail, and be responsible on the death of the twenty-one pilots. He appears having Machiavellian features of cunning and capable of deception, and at the same time, he is cool and unresponsive to the ethical and moral demands for social justice. This picture of Keller comes in terms with the findings of modern research concerned with the Machiavellian personality. According to High Machiavellian personality type, individual tends to demonstrate a depreciatory, hostile, and cynical view of people. Keller's scornful opinion towards others is consistent with the High Machiavellian type. In his description of the educated people who are working in his firm, he contemptuously says that "you stand on the street today and spit, you're gonna hit a college man" (p.96). 
Machiavellians are also described as having less of a conscience and showing less repentance, although it looks like that they "are not impaired in their ability to reason through moral dilemmas; they can see other's perspectives, but act selfishly nonetheless" (proposing a multidimensional Machiavellianism conceptualization by John F. Rauthmann and Theresa Will, 2011,p.400). In this vain, Keller knows deep inside what he has done of selling the cracked cylinders are unethical, yet he did it selfishly, regardless the fatal consequences. Moreover, he talks about his friend, Deever, who was jailed because of Keller's greed.

In a test experiment, the Machiavellians were goaded into cheating and then confronted by their dishonesty, the High Machiavellian personality looked at the experimenter in the eye boldly while denying the cheating and confessed to cheating less often than did Low Machiavellian personality types.

After his laying and denial, Keller realizes his crime when he reads a letter of his son, Larry, where he confessed that he killed himself because of his father's crime that his father was the reason behind killing his pilot friend. Yet, in doing so Keller blames his crime on his society shoulder, saying

Who worked for nothin' in the war? When they work for nothin', I'll work for nothin'. Did they ship a gun or a track outa Detroit before they got their price? Is that clean? It's dollar and cents, nickels and dimes, what's clean? Half the Goddam in gotta go if I go! That's why you can't tell me (Act:3, 125).

The Machiavellian main principle "the ends justify the means" is regarded as the basis of all his utilitarian and pragmatic perspective. Moreover, Machiavellian personality is "primarily concerned with the specifics of how to accomplish a goal and less concerned with ambiguous questions that pertain to whether or not a course of action is right or wrong, moral or immoral."

Furthermore, another characteristic of Machiavellian personality is that he has a keen sense of timing, as well as he is a goal oriented to the point of ignoring ethical considerations. In his game of policeman and jail with the neighbor kid, Keller declares to his wife Kate, who reproaches him for playing such a game, that he has nothing to hide and he is not guilty. He has "such a talent for ignoring things," and he admits to Chris, "I ignore what I gotta ignore." This is apparent in the way he relates what happened after his release. He proudly says:

The day I come home, I got out of my car... You should have been here, [ to Ann and Chris]... Everybody knew I was getting out that day; the porches were loaded. ... None of them believed I was innocent. The story was, I pulled a fast one getting myself exonerated. So I get out of my car, and I walk down the street. But very slow. And with a smile. The beast! I was the beast ... that day I was guilty as hell. Except I wasn't, and there was a court paper in my pocket to prove I wasn't. ... Fourteen months later I had one of the best shops in the state again, a respected man again; bigger than ever.(p.28)

Machiavelli in his book The Prince advices the prince to choose to be a lion instead to be a fox. This reflects the Machiavellian strife for power and control. In this respect, Arthur Miller portrays Keller with animal pictures, showing his animal side on one hand, and reflecting the dehumanization of man and the selfish and the materialistic mentality of the American society that concentrates on collecting money by any means or cost. Keller views life as a jungle where the strong eats the weak, reflecting Darwinian thought of survival for the fittest and the elimination of the weak.

Keller:... What could I do! I'm in business, a man is in business; a hundred and one cracked, you're out of business; you got a process, the process don't work you're out of business.... They close you up, they tear up your contracts,...you lay forty years into a business and they knock you out in five minutes, what could I do, let them take forty years, let them take my life away? (p. 67)

This philosophy of dehumanizing is criticized by Chris, who represents the romantic idealisms and the foil of his father, saying: "This is the land of the great big dogs, you don't love a man here, you eat him! That's the principle; the only one we live by-... This is a zoo, a zoo" (p.77). This picture that Chris uses to describe his society shows the critical abyss that man may find himself in and harshness of living in such cut-throat state.

Keller as a Machiavellian person uses tactics and strategies to achieve his goals. He eloquently and indirectly tries to convince others that Deever was responsible of the crime and at the same time he tries to show how a considerate person he is by offering a job to Deever when he will get out of prison. Keller tries to justify Deever's crime as if he is justifying himself. He explains that Deever was at fault 
because of the business and the situation he found himself in, yet we cannot call him a murderer. All what has happened is a matter of business in Keller's mentality.

Chris: He murdered twenty-one pilots.

Keller: What the hell kina talk is that?

Mother: That's not a thing to say about a man.

Ann: What else can you say? When they took him away I followed him, went to him ever visiting day. I was crying all the time.... It's wrong to pity a man like that.

Keller : The man was a fool, but don't make a murderer out of him. ... Just try to see it human, see it human. All of a sudden a batch comes out with a crack. That happens, that's the business. A fine hairline crack. All right, so-so he's a little man, your father, always scared of loud voices. What'll the Major say? - Half a day's production shot.... What'll I say? You know what I mean? Human.(He pauses) So he takes out his tools and he - covers over the crack. All right- that's bad, it's wrong, but that's what a little man does. (p.30-31)

In a conversation between George and Chris, the former remembers what happened to his father and how Keller used a tactic and a plan to escape the consequences of his action. Keller gave a telephone call to Deever informing him to ship the cracked cylinders and as there was no witness to their conversation, Deever became the scapegoat.

\subsubsection{Maslovian Reading to the Machiavellian Businessman in Miller's All My Sons.}

The previous section is an attempt to show Keller as a Machiavellian businessman. In the present section, the researcher aims to study the psychological factors that form Keller's Machiavellian personality, and to grasp his needs, his anxieties and his self defenses.

In the introduction to his collected plays, Miller admits that his play All My Sons, like all his plays, is written to give man a better understanding of Man and of his society. Joe Keller, as a businessman in a time of chaos and doubts caused by war, materialistic life, upheavals and uncertainty, wants to establish a successful business at any cost. For him success in business, which represents all his life, is an attempt to satisfy his needs and to gain or maintain a respected position in his society. However, his way of satisfaction and his search for position in life are hampered by certain interior factors within the character himself, or by some exterior forces within his environment. Keller's search involves also his relationships with others surrounding him which essentially shows his (dis)respect to the rights of others as "a man among men."

In their struggling for fulfilling his psychological needs, the businessman character does not meet responsibilities that have an effect on his nation, but, rather, he faces situations that directly impinge on his own lives. In Miller's drama, there is no kingdom at stake, and the character's choice does not change the route of history. However, that does not detract the character's struggle for his needs, yet it does mirror the composition of the modern world.

Keller is portrayed as a businessman with great ambition and motivation. He tries by all means to have a successful business and to have a position in his society. Keller's motivations, his personality and his needs to actualize his motivated dreams that turn him to be against the general current will be analyzed by Maslovian theory of hierarchy of needs. Maslow believes that the higher order needs such as esteem and selfactualization can only be fulfilled after lower order needs (physiological, security and love needs) are gratified (Fifty Key Thinkers in Psychology, Sheehy, p. 164). Thus, Keller's physiological needs must be secured before he can pursue other needs to reach the self-actualization level. However, there is no evidence in the play that Keller has any problem regarding his physiological needs as his business is prosperous. In developmental societies as in America, Maslow believes, the physiological needs are already satisfied (Motivation and personality, p17).

In Act One, Keller seems have gratified his fourth levels of needs, as he economically and socially lives in a secure state with a loving family, friends and neighbors and where he is respected and feared by them and by the workers of his firm, respectively. Yet, he is far from being self actualized person as he suffers from problems that will be revealed later in the play. Keller's personality is developed and exposed during the actions of the play. Before the incident of selling the cracked cylinders, Keller is assumed to climb up to self actualization according to Maslow's theory which states that all individuals strive towards their selfactualization. Yet, when his financial security was highly threatened by the government because he was late in producing the army cylinders, Keller, due to the business value has regressed to the lower levels of needs (the security and belonging needs). Maslow contends that when an individual is dominated by a certain need, his "whole philosophy of the future tends...to change" (Maslow, p.17). 
Therefore, Keller justifies his crime of sending the defective cylinders and killed twenty one pilots as urge needs to protect his family, his business and himself. In fact Keller is afraid from losing what he already posses. His family and their love are part of what he posses. Hence, if he was convicted of his crime, he surely would lose everything. His instincts for survival and domination are overwhelmed by the powerful forces of the business value and by the critical situation he was in. A matter that makes his only realism is the accommodation of his economic and power instincts. Bigsby (2010, p.55) argues that Keller's crimes against society "drive from the... instinct for self- preservation and self- assertion that foster the adaptation of a counterfeit innocence and the illusion of one's being a victim at the hands of others."

Maslow believes that human behavior is multi-motivated, saying that "[w]ithin the sphere of motivational determinants any behavior tends to be determined by several or all of the basic needs simultaneously rather than by only one of them" (Maslow, p.29). In All My Sons, Keller's behaviours are motivated by several needs that threaten him as they impose themselves on his existence as human being, man, father and husband. In rationalizing his crime, Keller shows the effects and the importance of these needs. Moreover, Maslow points out that the persisting and essential needs usually channel individual's thinking and perception, therefore, the individual only concentrates on the aspects of the environment or situation related to needs satisfaction. Hence, when Keller finds himself in a critical situation, vacillating between losing his business and what it represents to him, and keeping it at any cost, he tends to satisfy the needs of survival over ethics and morals.

Moreover, due to the close relationship between Keller and Deever families, the Deveers desertion of their father, leaving him a susceptible to loneliness in the prison, is sounded like a death warrant to Keller. Deever after being convicted has lost his sense of security, belongingness and acceptance from his family and society. His daughter Ann regards visiting him wrong deed saying: "It's wrong to pity a man like that. Father or no father, there's only one way to look at him. He knowingly shipped out parts what would crash an airplane. And how do you know Larry wasn't one of them?'(All My Sons). Presumably, if Ann's attitude is striking and so dispassionate towards her father, a son can also be the same. And that has haunted Keller. He feels terrified if truth is uncovered and his sons will know it and that makes him fractured between his needs to protect his status, his family and his needs of love and social acceptance.

Hence, Keller alleges that the importance of his family and "the power of bluff" have been implanted in him by the consent of his society. He claims that his way of achieving his needs is already accepted as it is part of American system that implicitly encourages such behaviours in this "cut-throat competition" (All My Sons, p.96).

Keller presents himself as merely a victim of motivated forces that restrain his choices. He addresses his son Chris when the truth is uncovered, saying

You're a boy, what could I do! I'm in business, a man is in business; a hundred and twenty cracked, you're out of business you got a process, the process don't work you're out of business; you'd don't know how to operate, your stuff is no good; they close you up, they tear up your contracts, what the hell's it to them? You lay forty years into a business and they know you out in five minutes, what could I do, let them take forty years, let them take my life away?

Keller tries to mitigate his guilt by clearing up that he only thought that the defective machinery would be returned to be fixed, hoping that the Air Force Army would discover the defaults of the aircraft parts. However, after being forced by Chris to admit his knowledge that the planes were likely to crash with the faulty engines, Keller justifies his actions by claiming that it is the needs of modern life, and it is concordant with the general code of ethics prevalent in American business during the war. He shouts belligerently:

Who worked for nothin' in that war? When they work for nothin', I'll work for nothin'. Did they ship a gun or a truck outa Detroit before they got their price? Is that clean? It's dollars and cents, nickels and dimes; war and peace, it's nickels and dimes, what's clean? Half the Goddam country is gotta go if I go! (p. 125)

In his theory of motivation, Maslow states his belief that human being is created to be good and the villainy is not essentially part of humanity; rather it can be explained by the lack of or unmet satisfaction of the individual basic needs. Dennis Wellend (1961, p.37) remarks:

Joe himself is perhaps too pleasant for the part he has to play. His betrayal of his partner seems out of key with his simple geniality and warmth of nature. As with most of Miller's characters, there is no vice in him, only littleness and his own form of myopia. 
That is also echoed by the prominent critic Harold Bloom (2007, p.7) describing Joe Keller as a villain without real intention of villainy. He is not portrayed as a good man; nevertheless he is portrayed like an ordinary man in his relation to his family, friends and neighbors. He is simply a man among men, a "man for whom there is still wonder in many commonly known things" (All My Sons, p). It is his business that leads him into what is described as "moral idiocy." Yet in his approaching to fulfill his dreams and desires he has a Machiavellian intelligence sharpened by his motivational system of survival and of success. In this respect, Dr. Jim, Keller's friend and neighbor, appreciates Keller's way of hiding the secret saying that "it takes talent-for lying" (All My Sons, p.118) and Keller is perfect in this.

Moreover, Maslow postulates that unethical or immoral behaviours may emerge among those who have grown over unmet needs. Through the action of the play, it appears that the most significant subject that preoccupied Keller is business and materialistic aspects of life. Maslow also indicates that the individual who has been adequately gratified in his lower needs early in life can develop a "frustration tolerance" that allows him to experience and tolerate later deprivation without critical regression. On the other hand, if the individual is not well satisfied in the early stage of development, he will be subject to regression. This is true with Keller. Although it is little known about Keller's childhood, it is mentioned that he was working since he was ten years old and he was deprived of good education. His early childhood has taught him that money is the Mammon god whose voice is thunderous. In a conversation with his wife, Keller furiously says:

I spoiled the both of you. I should've put him (Chris) out when he was ten

like I was put out, and make him earn his keep. Then he'd know how a buck

is made in this world. (All My Sons, p.120)

His early work to meet his security needs intensifies the sense of insecurity that remains standby with him. Hence, any threat to it, like economic instability, can cause him feeling of vulnerability. Keller comments on his financial success, saying proudly "once upon a time I used to think that when I got money again I would have a maid and my wife would take it easy. Now I got money, and I got a maid, and my wife is workin' for the maid" (All My Sons, p.70). The only thing he knows is capitalism and seeking power and money. Being an uneducated man he has faced the hardships of life in a very early age, he tries to cope with the rapid and feeble values of a society and business.

A very significant point is raised by Maslow through analyzing the satisfaction of needs. When individuals gratify their basic needs of security, belongingness, feelings of being loved and respected, they may gain psychological sufficiency and "external reward", related to their sense of happiness, peacefulness and serenity. However, the "evil people", whom their basic needs are already satisfied in part of their life, may be punished intrapsychically due to their regression to satisfy these needs for one reason or another. (Maslow, Abraham Harold; Stephens, Deborah Collins (2000): The Maslow Business Reader. New York: John Wiley \& Sons (141-142). This can partly illustrate Keller's uneasiness after his crime done after his regression to a lower level. Yet, Maslow does not fully elucidate what the intrapsychic conflicts that such individuals go through. As explain in chapter three, Horneyan theory is adequate to clarify the intrapsychic and interpsychic conflicts caused by thwarting of needs' satisfaction, so creating a personality that behaves in a Machiavellian way. So, the next section will explicate the psychological effects of the regression and the unmet needs on Keller's personality.

\subsubsection{Keller's Psychological Conflicts through Horneyan Lenses}

In his attempt at self-fashioning, Keller also defies social and cultural codes and challenge prevailing ideologies; however, because of their internal warring of defense modes and their inability to replace their idealized selves with realistic identities, the characters are unable to reach a point of self-actualization. Their attempts at autonomy are aborted, and each character retreats into the third stage of Horney's theoretical development-detachment or withdrawal from societal interaction.

In a civilization that is in rapid transition with contradictory values and ways of life existing concurrently, Horney asserts, "the choices an individual has to make are manifold and difficult" (Our Inner Conflict 24).

The emphasis that Horney places on cultural and environmental factors makes her psychoanalytic theory amenable to many contemporary theoretical approaches, especially cultural materialist thought which posits that subjectivity is determined by cultural and material conditions within a given society.

In her theory of basic anxiety, Horney states that the individual experiences anxiety or psychological conflicts due to his feelings of insecurity in interpersonal relations. Horney, moreover, observes that such individual recognizes his environment as "dreaded as a whole because it is felt to be unreliable, mendacious, unappreciative, unfair, unjust, begrudging and merciless... He feels in danger of his individuality being obliterated, his freedom taken away, his happiness prevented" (Horney, 1939). Likewise, Keller, threatening by the government to demolish his business and success, he has experienced an anxiety and interpersonal conflicts that led him thinking of certain self mechanism to relieve such conflicts. Horney conceives that "unfavorable 
conditions" individual develops "a profound insecurity and vague apprehensiveness" (Horney, 1950, p.18) and a "feeling of being isolated and helpless in a world conceived as hostile." Keller is torn by different responsibilities that burden his psychological stability. One hand, he is in a competitive business and merciless world that urges him to find means to survival at any cost. On the other hand, his love for his family, his security needs, his being as a respected and loved person among his people, his ambition and his friendships duty towards his friend and work partner Steve Deever are all "unfavorable conditions" that create interpersonal and intrapersonal conflicts. As a result Keller forsakes his real self and develops neurotic strategies and solutions for coping with his environment.

One of the earlier strategies that Keller develops is the aggressive or expansive solution where he, in Horney's term, moves against people. For Horney the basic anxiety is socially and culturally based. Hence, the business culture in America in general and Keller in particular is seen rooted in capitalistic competition. Horney maintains that "among the factors in western civilization which engender potential hostility, the fact that this culture is built on individual competitiveness properly ranks first (Horney, 1950, p. 173). This is certainly true for Keller, who finds himself in a hostile business world and that, in one way or another, is driven to conquer and exploit others for his own sake. In a Machiavellian way, he exploits his innocent friend Deever and involves him into the crime of selling the defective cylinders to the Army Air Force.

Keller explains his capitalistic philosophy that business is a matter of life and death, saying

Keller:...You mean... you'd leave the business?

Chris: Yes. On this ground I would.

Keller: ... well ... you don't want to think like that.

Chris: Then help me stay here.

Keller: All right, but-but don't think like that. Because what the hell did I work for? That's only for you, Chris, the whole shootin' match is for you! (I, p.69)

The phrase "shooting match" portrays a war-like atmosphere where Keller is a warrior who has to fight and kill others if necessarily, applying the jungle instinctive law of "The survival of the fittest." Keller considers war as a sort of business where he has either to die and let others survive, or to be a victimizer and make great warprofit regardless of others. Being in a materialistic society that based on worshiping the success at any price, Keller has chosen to be the latter to achieve his goals at the expense of humanity. In his relationship with others, especially in his work field, Keller shows a kind of ruthlessness and cynicism. His aggressive trends to master his life make him appear tough and hard. He fears manifestation of his complaint feelings as they may make him susceptible in an evil world. He is a man that will not "let a hundred and twenty one cylinder heads be repaired and shipped out of his shop without ... knowing it ... He even knows how many minutes a day his workers spend in the toilet" (All My Sons).

Keller's cruelty and ruthlessness are further described by his son Chris when the secret is discovered:

What the hell do you think I was thinking of, the Goddam business? Is that as far as your mind can see, the business? What is that, the world of business? What the hell do you mean, you did it for me? Don't you have a country? Don't you live in the world? What the hell are you? You're not even an animal, no animal kills his own, what are you? What must I do to you? I ought to tear the tongue out of your mouth, what must I do? (With his fist he pounds down upon his father's shoulder) (All My Sons, p.)

Moreover, Keller as being live within a competitive society, he "can only develop an urgent need to lift himself above others" (Horney, 1950, p.21). To alleviate the basic conflicts caused by war, Keller adopts an interpersonal strategy that Horney calls "moving against people" where he becomes what Horney calls "the hostile type." Keller's strategy is largely driven by insecurity, anxiety and hostility and his adjusted pattern of behavior is combined by the neurotic needs for power, for respect, for prestige, for exploitation and manipulation of others, and for personal achievements. Nevertheless, as Horney postulates, this person of hostile behavior has a double face. He is capable of acting politely and friendly but they are means to an end. Significantly, Horney describes such pattern of behavior a Machiavellian behavior due to the close relationships between this type of behavior and that of Machiavellianism.

By using his Machiavellian strategy to cope with business culture, Keller's genuine feelings and morals are silenced in favor of immediate safety needs and the instinct of survival. The more his legitimate feelings of ethics and values are silenced the more Keller's real self retreats into the background. The background yard that the play starts with may resemble Keller's retreated real-self where the apple tree, planted as a memorial of Larry, represents his crime of killing the pilots. In All My Sons, Miller aptly states that 
There [is]...always the choice, always the conflict between [Keller] own needs and the desires and the impediments others put in his way. Always, and from the beginning, the panorama of human beings raising up in him and in each other the temptation of the final solution to the problem of being a self at all -the solution of obliterating whatever stands in the way, thus destroying what is loved as well.( the Cambridge Companion to Arthur miller by Christopher Bigsby, p.52)

However, in the character's "imagination sets", this inaccessible real self has "gradually and unconsciously... created...an idealized image" (Horney, 1950, p.22). For Keller, his idealized self-image chooses a solution of Machiavellianism and of aggressiveness. He, according to Horney's theory, glorifies this solution to represent his "strength, leadership, heroism, [and] omnipotence" (p.22). His idealized-self is his "comprehensive neurotic solution" to satisfy not only his instant needs to resolve his anxiety of self-protection, rather it replaces his real self with a self that is much more in harmonious with the standards and expectations of a competitive culture. By getting his friend involved in the act of criminality, and getting himself out of it, pretending to be honest a and showing care to his friend's fate, Keller demolishes his real-self, replacing it by what is expected from a materialistic businessman finds himself in economic predicaments. His ambition for external success becomes his compulsive drive to be "one of the best shops in the state again, a respected man again, bigger than ever" (All My Sons, p).

Horney believes that the individual "tries to actualize his ideal self with regard to the outside world" (Horney, p.68). Likewise, Keller's egocentric capitalistic thinking urges him to actualize his idealized selfimage by justifying his crime as a necessity to meet the values and ethics of the business outside world, confirming the threat that "community ethics rests on moral chaos" (John Russell Brown, 1986). All My Sons is meant to probe into a time of "widespread moral ambivalence... [where] trivial and large cheating was commonplace" in post- Depression America (Freedman, 1971, p. 83).In this aspect, Keller is portrayed as a character thrown into sharp struggle that trammels his choices.

Keller's struggle to stay away from his real self-image forces him to maintain a degree of innocence that should in return convince the characters around him. He circumvents Ann's accusing looks and tries to persuade her that her father "never learned to take the blame' (all My Sons, p. ). He even proposes to find a job after he is released from jail: "I want him to know that when he gets out he's got a place waiting for him. I'll take him bitterness."

Ironically, though Joe Keller is a victimizer, he himself becomes a victim to the "Tyranny of the Should" (Horney, 1950, p. 65) through which he tries to "search for [his] glory" and establish his idealized self image. These "shoulds" are largely based on the expectations and stereotypes of behaviours and qualities generated by certain community "whipping a person into action in the attempt to actualize the ideal self" (Horney, 1950, Neurosis and human growth). Keller is subjected to the pressure of personal and cultural shoulds. He claims that he should protect his family as "nothin' is bigger than the family", he should be a master of his fate and the fate of the others, and he should be a successful businessman and lovable person from all his people surrounding him. He selfishly betrays his friend to jail and then tells Ann that he is ready to give him a job when he will be released. Because "This is the land of the great big dogs, you don't love a man here, you eat him! That's the principle" (p. ) Keller uses his friend as a scapegoat, regarding him a weak person that should be eliminated. Moreover, he wants to feel that all the strings of game are in his hands. He considers his actions as authentic, stemming from a man who knows what he is doing while others like his friend Deever are merely fools. Keller describes his friend as being "a little man, ..., always scared of loud voices."

At the expository scene, Miller draws a clear-cut picture for Keller, as representing ignorance, rudeness and indifferent feelings towards others:

A heavy man of stolid mind and build, a business man these many years, but with the imprint of the machine-shop worker and boss still upon him. When he reads, when he speaks, when he listens, it is with the terrible concentration of the uneducated man for whom there is still wonder in many commonly known things, a man whose judgments must be dredged out of experience ....

Keller is so proud of his business achievements that he got in spite of his nonacademic accomplishments. And that adds to his pride system through which he hides his real self. Eventually, the whole atmosphere of the family reminds him of his crime, yet he avoids self-confrontation, believing that one cannot live honestly whereas corruption is everywhere around. This is "the way the world is made" (All My Sons, p). In Horney terms, the neurotic individual knows that his self- image is an unsatisfactory version for his real-self. Moreover, Horney assures that the idealized self provides only an illusory sense of worth, alienating the neurotic 
from the true self. Yet, his real self image is not totally dead; rather it projects itself in a process Horney names as externalization. This projection is temporarily mitigating the basic anxiety caused by the conflicts and discrepancy between the two self- images. Yet, it cannot reduce the gap between the real and idealized-self images. In this regard, Keller's jail-game with neighbor's children is projection of the two self-images conflicts onto the outside world. He tells Bert that "on my word of honor there's a jail in the basement" (All My Sons, p. ). Keller's conversation with his wife, Kate, shows that though Keller hides his crime from others, hence, hiding his real-self, he is aware that his self is not the real one:

Mother: I want you to stop that, Joe. That whole jail business!

Keller: $\{$ alarmed, and therefore angered $\}$ Look at you, look at you shaking.

Mother: \{trying to control herself, moving about clasping her hands\} I can't

help it.

Keller: What have I got to hide? What the hell is the matter with you Kate?

However, Horney suggests that any crack in the neurotic's idealized self-image will threaten his false sense of power and security. She symbolizes the neurotic self- image as "a house [that is] filled with dynamite" (Theories of Personality By Duane P. Schultz, Sydney Ellen Schultz, p.170). As a case in point, Keller's house can be viewed as a house loaded with such dynamite that is ready to explode and to challenge Keller to face his real hidden self- image. The fuel of this dynamite is agitated by the coming of Ann and George, by the idealism of his son Chris and finally by the letter of his son Larry that becomes the last straw in shaking, cracking and eventually destructing his idealized self image.

Keller is ambivalence between his idealized self-image and his despised image, "with no solid middle ground to fall back on" (Horney, 1945, p. 112). His moral predicament is not cause mainly by his concern for family, but by something deeper. Miller explains his protagonist's "trouble" as being part of "his cast of mind [which] cannot admit that he, personally, has any viable connection with his world, his universe, or his society." Keller's idealized self-image that is based on the philosophy of "survival for the fittest" and that might makes right is changed into self-despise when it is faced by the fact that hiss idealized image is an illusory one, not a real one:

Chris: (with burning fury) For me! Where do you live, where have you come from? For me! ...I was dying every day and you were killing my boys and you did it for me? What the hell do you think I was thinking of, the Goddam business? Is that as far as your mind can see, the business? What is that, the world of business? What the hell do you mean, you did it for me? Don't you have a country? Don't you live in the world? What the hell are you? You're not even an animal, no animal kills his own, what are you? What must I do to you? I ought to tear the tongue out of your mouth, what must I do? ()

Upon recognizing how far his real self is and how all his means to meet his needs and dreams are invalid, Keller finds himself losing everything. He has been defeated by himself as well as by his society that once supports him. He finds himself in a situation of losing every things; his family, economic security due to the secret revelation, his false-image emitted from a false ideal system and which he dedicates himself to it. Hence, this realization makes no choice for him but only committing suicide.

\section{Conclusion}

Holding a mirror up to the society, Miller in All My Sons shows that the American capitalism and technological development forge human needs and create illusionary dreams. Yet, Keller's crisis is not merely caused by capitalistic economy; rather his predicament is Every man predicament, a predicament that is generated by different cultural, political and economic forces. Tragically, in the modern world that is based on the specification in different field of knowledge, yet everything is interrelated with the energies existing within the society. Miller in his drama tries to challenge Machiavelli's thought in The Prince and the psychological theory emitted from it that have narrowed the mind of people to get success at any cost.

\section{References}

[1] R.Christie \& F. L. Geis, Studies in Machiavellianism (New York: Academic Press, 1970).

[2] John Roe, Shakespeare and Machiavelli (Cambridge: DS Brewer2002).

[3] Edward Stockton Meyer, Machiavelli and the Elizabethan Drama (Weimar: E. Felber, 1897).

[4] Khoury, Joseph, Machiavellian providential politics in Marlowe and Shakespeare: A comparative perspective, doctoral diss., Carleton University 2001.

[5] Wilbur Sanders, The dramatist and the received Idea: studies in the plays of Marlowe and Shakespeare (Cambridge: Cambridge Up, 1968). 
[6] H. Grady, Shakespeare, Machiavelli, and Montaigne: power and subjectivity from Richard II to Hamlet ( Oxford: Oxford university press, 2002).

[7] Gable Myron \& Martin T. Topol, Machiavellian managers: Do they perform better?. Journal of Business and Psychology, (1991) vol. 5 , no. 3 .

[8] Jean Phillips and Stanley Gully, Organizational behavior: tools for success (Wadsworth: Cengage, 2012).

[9] S. Tobias, The effects of assertiveness training on Machiavellianism (Union, NJ: Kean College of New Jersey, 1982).

[10] A. A. Turnbull, Selling and the salesman: Prediction of success and personality change. Psychological Reports, 38(4), (1976). 1175-1180.

[11] R. L. Wakefield, Accounting and Machiavellianism. Behavioral Research in Accounting, ((2008), $20(1), 115$.

[12] Robert M Jiobu, Ethnicity and inequality (Albany: State University of New York Press, 1990).

[13] Hardeo Ojha, Parent-child interaction and Machiavellian orientation. Journal of the Indian Academy of Applied Psychology,. (2007). Vol. 33, No.2, 285-289.

[14] Karen Horney, The neurotic personality of our time ( New York, NY: W. W. Norton \& Co, 2007).

[15] B. R. Hergenhahn, An Introduction to the history of psychology (Belmont, CA: Cengage Learning/Wadsworth, 2008)

[16] Bernard J.Paris, Imagined human beings: A psychological approach to character and conflict in literature (New York University Press, 1997)

[17] Abraham Maslow,Twoard psychological of being ( New York: Van Nostrand, 1968).

[18] Karen Horney, Neurosis and human growth: The struggle toward self-realization (New York, NY: W.W. Norton \& Co., 1950).

[19] Bernard J Paris, A psychological approach to fiction: studies in Thackeray,Stendhal, George Eliot, Dostoevsky, and Conrad (Bloomington: Indiana University Press, 2010).

[20] Gregory Kimble and Michael Wertheimer, Portraits of Pioneers in Psychology (Washington, D.C.: American Psychological Association, 2000)

[21] Karen Horney, Our inner conflicts. New York, NY: W. W. Norton \& Co, 1945).

[22] Duane P. Schultz, Sydney Ellen Schultz, Theories of personality (Belmont, CA: Wadsworth. Sommerfeld, 2008)

[23] Matthew H Olson, B. R. Hergenhahn, An Introduction to Theories of Personality (Belmont: Wadsworth, 2008).

[24] Karen Horney, New ways in psychoanalysis ( New York, NY: W. W. Norton \& Co. 1939).

[25] Richard I. Evans, Psychology and Arthur Miller (New York: E.P. Dutton. 1969).

[26] Matthew Charles Roudané, Public issues, private tensions: contemporary American drama (New York: AMS Press, 1993)

[27] Christopher W. E. Bigsby, Modern American drama, 1945-2000 (Cambridge: Cambridge UP, 2000)

[28] Arthur Miller, All My Sons, in Arthur Miller's collected plays, vol. 1 (New York: Viking Press, 1957)

[29] John F. Rauthmann and Theresa Will, Proposing a multidimensional Machiavellianism conceptualization, Social Behavior and Personality, 39, 391-404, 2011.

[30] Christopher Bigsby, The Cambridge Companion to Arthur Miller, Cambridge/New York: Cambridge UP

[31] Dennis Welland, Arthur Miller ( England: Oliver and Boyd, 1989)

[32] Harold Bloom, Arthur Miller: modern critical views ( New York: Chelsea House Publishers, 1987).

[33] Abraham H. Maslow, Deborah C. Stephens, The Maslow business reader (New York: John Wiley \& Sons, 2002). 